\title{
Scaling social franchises: lessons learned from Farm Shop
}

\author{
Kevin McKague ${ }^{1 *} \mathbb{C}$, Farouk Jiwa ${ }^{2}$, Karim Harji ${ }^{3}$ and Obidimma Ezezika ${ }^{4}$
}

\begin{abstract}
Background: The challenge of enhancing food security and livelihoods for smallholder farmers has been a significant concern in the agricultural development field. To increase farm productivity and enable smallholder farmers to rise out of poverty, several organizations have initiated social franchising business models to create sustainable social enterprises. Social franchising has recently gathered increased interest in lower-income countries for its potential to address social and ecological issues, support local entrepreneurs, and reach financial sustainability to allow for scaling through market forces. Social franchising combines the principles of business franchising (standardized systems and other supports that reduce risk for the entrepreneur) with a social mission. To gain deeper insights into the opportunities and challenges for scaling social franchises, we gathered quantitative and qualitative longitudinal data on Farm Shop, a social franchise with a network of 74 agricultural input shops seeking to reduce food security through improving productivity, incomes and food security of smallholder Kenyan farmers.

Results: We derived five critical lessons from our findings. First, social franchising can create jobs and profitability for farmers and strengthens the rural entrepreneurial ecosystem. Second, economics of scale is critical for profitability and sustainability of the social franchisor. Third, building trust with farmers is crucial for a successful social franchising model. Fourth, social franchisors should be aware of the variety of options to ensure the sustainability of the social franchising program. Fifth, to develop a scalable business model, cost-effectively gathering the right data to validate key assumptions is essential.

Conclusions: Farm Shop is one of a cohort of pioneering social franchises that have applied the principles of franchising to address particular social needs. In this case, the needs were food security, livelihoods, and prosperity for smallholder farmers. Farm Shop uncovered important lessons relevant for all social franchises at similar stages in the business model development process. With these lessons in mind, Farm Shop and other social franchises can be better equipped to live up to social franchising's promise of achieving social objectives in a more resource-efficient and sustainable way.
\end{abstract}

Keywords: Social franchising, Agriculture, Food security, Smallholder farmers, Productivity, Kenya, Social enterprise

\section{Introduction}

Agriculture has a significant role to play in poverty alleviation for most developing countries and regions [13]. It is also an essential component of growth for the poorest agriculture-dependent economies and critical in the fight

\footnotetext{
*Correspondence: Kevin_McKague@cbu.ca

1 Shannon School of Business, Cape Breton University, Sydney, Canada

Full list of author information is available at the end of the article
}

against poverty [4]. The majority of the world's population living in rural areas and referred to as being "poor" depend on agriculture for their livelihood and practice smallholder farming [13]. Although smallholder farmers are vital to developing the world's agriculture [11], they still face a myriad of challenges, including insufficient information, lack of capital, lack of technical knowhow and lack of access to improved seeds, fertilizers and other productivity-enhancing inputs [21, 29]. Optimal

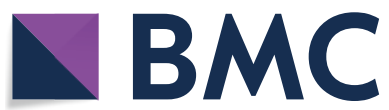

(c) The Author(s) 2021. This article is licensed under a Creative Commons Attribution 4.0 International License, which permits use, sharing, adaptation, distribution and reproduction in any medium or format, as long as you give appropriate credit to the original author(s) and the source, provide a link to the Creative Commons licence, and indicate if changes were made. The images or other third party material in this article are included in the article's Creative Commons licence, unless indicated otherwise in a credit line to the material. If material is not included in the article's Creative Commons licence and your intended use is not permitted by statutory regulation or exceeds the permitted use, you will need to obtain permission directly from the copyright holder. To view a copy of this licence, visit http://creativeco mmons.org/licenses/by/4.0/. The Creative Commons Public Domain Dedication waiver (http://creativecommons.org/publicdomain/ zero/1.0/) applies to the data made available in this article, unless otherwise stated in a credit line to the data. 
productivity results rely on farmers' capacity to access and use, among other things, nutrients, seeds, pest management technologies, tools and knowledge $[5,15]$. To overcome these challenges, governments, NGOs, and private sector organizations pursued various strategies. These strategies have included increased access to inputs and markets, training on good farming practices, creation of productive assets, provision of microinsurance services, provision of climate information services, provision of energy services and provision of improved household storage and post-harvest facilities [33].

The challenge of measuring and enhancing food security and livelihoods for smallholder farmers has been a significant concern for stakeholders such as private sector organizations (including social franchises) in the agricultural development field [31]. To increase farm productivity and enable millions of smallholder farmers to rise out of poverty, several organizations have initiated franchising business models (called social franchising) to create sustainable social enterprises. Some of these have included Honey Care Africa, SIDAI, Babban Gona, Krishi Utsho, and Farmers Pride [2], Farm [14, 17], Kenya [19, $22,25]$.

\section{Social franchising}

In recent years, the concept of social franchising has attracted increasing interest for its potential to achieve social impacts in underserved markets in ways that are scalable $[10,20]$. Many organizations in various sectorssuch as Farm Shop in agricultural inputs-have begun to test this hypothesis through establishing and growing social franchises to address underserved needs in food security [23].

Business franchising is a standardized and replicable business system for a business unit, such as a shop, that reduces risk for the local entrepreneur owner-managers [20]. Social franchising (also known as microfranchising) is the application of principles of business franchising to achieve a social objective $[2,7,10,20]$. What makes social franchising unique is that in addition to providing a social benefit to end users (e.g., farmers), social franchises also support local business owner-entrepreneurs through support systems built into the business model (e.g., training, increased access to financing, assistance meeting government regulations, and a more efficient supply chain) [26].

The parent franchisor organization identifies an opportunity to address a social or ecological problem like food security through developing a franchising business model. It then enrolls entrepreneurs to enter into an agreement to run individual business units (shops) according to the concept developed by the franchisor. When an entrepreneur joins a social franchising network, they benefit from the work that has gone into developing and refining the particular model. In addition, they benefit from being associated with a recognized brand, being able to source from an efficient supply chain, being able to utilize economies of scale, and being able to access training, finance and other support and professional services. In return, franchisees are often required to adhere to quality and customer service standards, share business information and generate a revenue stream for the parent franchisor through margins on products sold, fixed payments, or some combination of the two.

\section{Social franchising in agriculture}

Social franchising in agriculture is relatively new globally. However, it is prevalent in other businesses like health care, sanitation, solar energy, education and clean water where service quality is crucial to maintaining brand equity [33]. Agricultural social franchising has recently begun to expand to countries such as India [22], Nigeria [2], Kenya [14], Bangladesh [25] Ghana [7], and China [32].

In Asia, there are social franchises such as Krishi Utsho and Huishang Nongiafu. CARE, a non-governmental organization, initiated Krishi Utsho in Bangladesh, which provides access to affordable, quality agricultural input and services needed by small farmers to increase their dairy and other agriculture outputs [26]. It also supports their integration into the agriculture value chain in a financially sustainable manner [22]. In China, a social franchise called Huishang Nongjiafu takes advantage of a large pool of qualified agricultural technicians, farmers willing to pay for agricultural services, and high prices of farming inputs [32]. The franchise provides training to farmers with the support of their trained franchises and local government, captures the most talented and entrepreneurial agricultural technicians and officials from the local state, and recruits franchise store owners who have agricultural training, influence, and standing in the local community.

In West Africa, examples of social franchises include Babban Gona and Fan Milk. Babban Gona is a social enterprise created as an innovative agricultural franchise model that provides professional management and investment for grassroots farmer groups in Nigeria [2]. Babban Gona's holistic end-to-end service delivery model has resulted in farmers reducing their input costs, increasing their yields, realizing a higher price for their products, and more than tripling their incomes. Another social franchise is Fan Milk, a dairy product company in Ghana that distributes its products via micro franchise vendors on bicycles [27]. The vendors purchase their cooler-equipped bicycles and their inventory of milk, popsicles, ice cream, and yogurt in advance. They are 
required to save a specific percentage of their $17 \%$ profits daily.

In East Africa, there are agricultural social franchises such as Farm Shop, Seed, Stock and Supplies (SSS), and Farmers Pride Agro-dealers [9]. All were created in response to a critical challenge in Kenya-no effeciteh SSS was created in response to a critical challenge in Kenya-no efficient system for getting farm inputs to the majority of people who need them, which negatively impacted their productivity, food security and income.

\section{Methods}

\section{The design and implementation of Farm Shop}

Based on our collective experience in studying, advising and creating social franchises in Kenya, Bangladesh, Zambia, Uganda, Mali and India [18, 24, 26], we have found that, generally speaking, local entrepreneurs can usually be supported to achieve business unit profitability (i.e., at the level of shop). In our experience, the biggest challenge by far that all social franchisees face across various sectors and countries, is finding a business model that can cover all the costs of the parent franchisor (including opportunity costs of capital and startup costs) so that the network as a whole can scale. Many organizations that have established franchising models to address social needs are in the middle of this process of experimenting with, developing and validating their business model with this core challenge in mind. One of the organizations experimenting with this central social franchising challenge is Farm Shop, a Kenyan agricultural inputs social franchise.

Farm Shop was founded in 2012 by Ashoka Fellows Farouk Jiwa and Madison Ayer to enhance smallholder farmer partner productivity, incomes and food security by providing increased access to affordable quality agricultural inputs. By 2020, Farm Shop had grown to a network of 74 shops serving 30,000 smallholder farmers, $50 \%$ of whom were women. Farm Shop's vision was that if it could reach financial sustainability (cover its costs of capital), it could scale to a network of hundreds and then thousands of shops in Kenya, East Africa and beyond.

With the core challenge of sustainability and scale in mind, in 2015, Farm Shop partnered with a team of researchers and collaborators and received implementation research funding from the International Development Research Centre and Global Affairs Canada under the Canadian International Food Security Research Fund (CIFSRF), which aimed to "to scale up research results and innovations to reach more people and have a greater impact globally to improve food security" (Canadian International Food Security Research Fund. Call for Proposals, 2015). An earlier round of grants had focused on incubating innovations to improve food security, such as new vaccines, seeds and fortified foods. The second grantmaking phase shifted emphasis to understanding how innovations could be scaled through private sector organizations like Farm Shop. The research project with Farm Shop was unique in CIFSRF's portfolio in that Farm Shop was a social franchise rather than a traditional research center, non-governmental organization or development project.

The original idea for Farm Shop emerged from Farouk and Madison's previous work together at Honey Care Africa, a social enterprise operating in Kenya, Tanzania and South Sudan, which is now East Africa's largest producer of honey [18]. When Honey Care Africa needed a business partner to distribute beehives and bee-keeping equipment to rural farmers in Kenya, they could not find any organization with a modern, efficient, coordinated distribution network to supply to smallholder farmers. Seeing this challenge and opportunity, the idea for Farm Shop was born.

The research team conducted 53 interviews between 2015 and 2020, 35 with Farm Shop managers, staff, franchisees and farmers, five with agricultural sector stakeholders and industry experts and 13 with other social franchises in the agriculture, health, education, sanitation, and consumer goods sectors. Two hundred and fifty-four pages of archival data (annual reports, management briefings, training materials, and other organizational documents) were reviewed along with monthly quantitative franchisee assessment reports from the management information system. Detailed monthly financial data were also reviewed and used to construct a financial model and dashboard of Farm Shop's operations.

Farm Shop's business model was being developed to help address the world's food security challenge where, globally, 795 million people are food insecure [12]. The World Bank's research has identified that if supported correctly, growth in the agricultural sector can be at least twice as effective at reducing food insecurity, alleviating poverty and improving the lives of smallholder farmers than growth in other sectors $[6,8]$. However, to be successful, agriculture-led growth requires a revolution in productivity and profitability in smallholder farming [28]. While green revolutions have more than doubled agricultural productivity in most of the world, Africa has shown very little relative improvement [6]. This stagnation in African agricultural productivity is due to many factors, including the lack of access to productivity-enhancing inputs and agricultural knowledge in rural areas because of high transaction costs, limited infrastructure, limited institutions and lack of economies of scale [6]. Perceiving these challenges, various donors have developed projects to support agricultural input shops, however, these 
initiatives have not been financially sustainable or successful in achieving scale [29].

In establishing Farm Shop, Farouk and Madison were conscious of the strengths and weaknesses in the institutional environment in Kenya. Their target market-smallholder farmers-were poor, geographically disbursed and risk-averse with low levels of literacy and cognitive bandwidth $[1,16]$. Women farmers faced additional constraints, such as more limited access to credit and greater household workloads and responsibilities [25]. An additional challenge was that crops and livestock varied from region to region due to local factors, such as proximity to markets, and larger factors such as agro-ecological soil and climate conditions. Local entrepreneurs that could become franchisees often had limited business skills and discipline around reinvesting profits from sales back into inventory. The value chain from formal sector suppliers of agricultural inputs (e.g., feed, seed, fertilizers, medicines) to independent shops was fragmented with limited economies of scale and uncertain levels of product quality and reliability. Farm Shop developed its social franchising business model in this context in order to remove obstacles and reduce risks for farmer and franchisees. Like other social franchises, the key challenge to scale would be to develop a business model that would generate enough income to cover the overhead costs of the parent franchise organization. Farm Shop generates revenue on the margins it earns between purchasing agricultural inputs from suppliers and selling them to franchisees (Fig. 1).

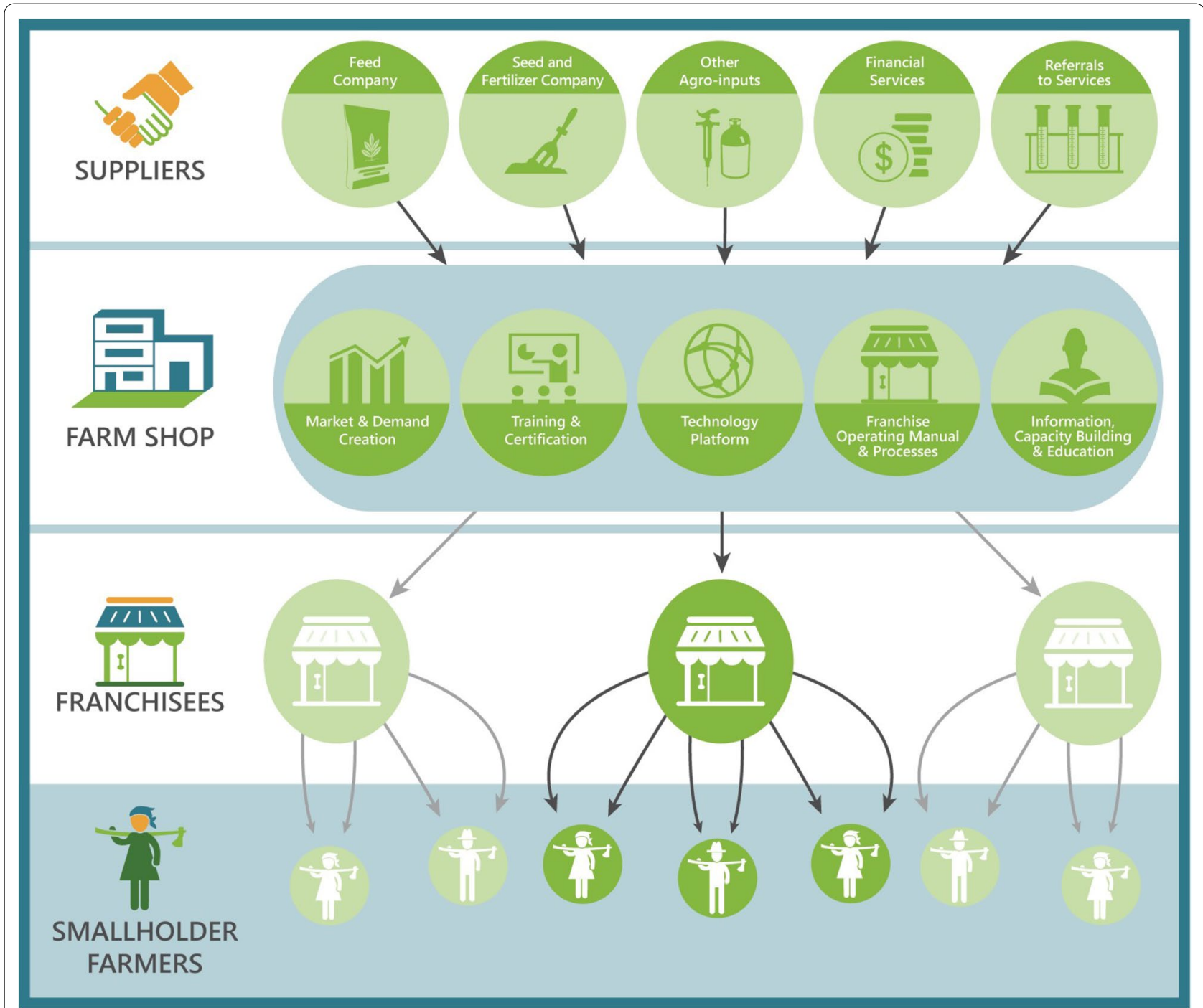

Fig. 1 Farm Shop's social franchise business model 


\section{Results and discussion}

Based on our experience and longitudinal data on the development of Farm Shop, we delineate five vital lessons for social franchises.

\section{Lesson 1. Beneficial to farmers: social franchising can create jobs and profitability for farmers and strengthens the rural entrepreneurial ecosystem}

Farm Shop sells about 700 different items in eight major product categories: animal feeds, veterinary medicines, minerals, day-old chicks, seeds, fertilizers, agrochemicals and equipment. They also refer farmers to a variety of services, including veterinary services, artificial insemination and soil testing. Farm Shop more or less doubled its number of shops every year in its early years, with 12 shops in 2014 and 25 in 2015 and 48 in 2016. As Farm Shop grew, increasing evidence was accumulating that the open shop format, quality products and an informative and helpful service model was benefiting farmers as well as the broader rural entrepreneurial ecosystem. For example, other local agro-dealer shops began to copy the open shop format and layout of Farm Shops. As the highest form of recognition of Farm Shop's successful concept, competitors began to enter the market to start a similar franchise networks.

Lesson 2. Expand to sustain: economies of scale are critical for profitability and sustainability of the social franchisor In the early stages of business model development before it opened its first shop, Farm Shop drew on research and the founders' experience in several countries to estimate that, with some small but critical improvements in the existing supply chain, an average shop might sell US $\$ 5000$ per month with a $10 \%$ margin retained by Farm Shop. With headquarters' over heads at roughly US $\$ 1 \mathrm{M}$ annually, initial estimates were that the network could break-even at around 150 shops.

As Farm Shop grew quickly and expanded, management worked overtime to develop information systems that could test the fundamental financial assumptions on which the scalability of its model was based. Developing the accounting, inventory and point-of-sale systems was a challenge in itself, as the pieces were costly and complex to integrate with few local suppliers able to provide a comprehensive solution. However, when data began coming in, it revealed several issues with the business model within the categories of margins, overheads, and franchisee profitability that would need to be quickly addressed if Farm Shop was to stay on a trajectory toward break-even and scale.

Farm Shop found that fewer of its franchisees were as profitable as had been anticipated. In some cases, new shops were costing Farm Shop more than were generating in sales margins once the indirect costs of marketing and support were factored in. Supporting all franchisees required much more Farm Shop staff time than initially expected and despite this, the franchise failure rate remained stubbornly high at $10 \%$ annually.

The data coming in based on Farm Shop's accounting and inventory management systems were unequivocal. Without any changes, Farm Shop would not break-even and could not scale. Farouk, Madison and their senior management team therefore reacted with a series of strategies to increase revenues and reduce costs to get the organization back on a trajectory toward break-even and scale.

After several months of putting its new strategies in place to reduce costs and increase revenues, Farouk, Madison and the research team recalculated Farm Shop's trajectory with the help of a specially developed financial model. Based on a number of assumptions about how the future will unfold, projections were that Farm Shop should now be able to break-even at about 500 shops.

\section{Lesson 3. Focus on trust: building trust with farmers is essential to a successful social franchising model} Farm Shop's approach was primarily a conversion-franchising model where existing independent agro-dealer shops would be converted into Farm Shop-branded shops. In Kenya, the norm is for existing agro-dealer shops to be operated behind metal bars where customers cannot browse products, see prices or choose between various product offerings. As a result, a sense of distrust between farmers and shop owners was generated. Farmers cannot tell by looking if feeds have fillers, if seeds will germinate into the varieties promised or if animal medicines are expired. Because of these constraints that smallholder farmers faced, including their vulnerability to the climate and inability to reverse purchasing decisions, building trust with farmers was essential to Farm Shop's social franchising model.

One way this was achieved was a markedly different shop format and relationship between farmer-customers and franchisee business owners. Premises were open to allow product inspection and comparison, prices were clearly labeled on all products and shop owners were trained to provide information to farmers on selecting products that would best meet their particular needs. All products were sourced through reputable suppliers to guarantee quality and authenticity, and shop owners and their shop assistants received training in customer care, agricultural practices and animal husbandry so they could help farmers make the best choices for their livelihoods and food security. 
Lesson 4. Increase revenue, reduce cost: a variety of options exist for the social franchisor to create sustainability

If each new shop costs the franchising network more than it generates, the system will scale itself out of business. Social franchises like Farm Shop operate in contexts with a lot of uncertainty-uncertainty about farmer, franchisee, supplier and competitor behavior and preferences. In the early stages of launching and building a new venture, many assumptions act as placeholders until they can be validated. The path to scale can be seen as a continual process of making assumptions and learning whether they are true or not and continually adjusting based on feedback and data from experience in the market. As a Farm Shop board member stated, "One of the things we have been promoting at Farm Shop is that all staff understand that we're on a journey, we're discovering new things, that we don't know the answers". Fundamentally, before an organization can scale, it needs to validate the financial assumptions underlying its business model and establish a clear path to profitability and scale.

\section{More company-owned stores}

Farm Shop's original business concept was to have franchisees own all shops. However, after a few franchisees failed to operate successful businesses in otherwise promising locations, Farm Shop took over the ownership and management of six of these shops and found that average margins it could earn were about 6\% higher than in franchisee-owned shops. Farm Shop began to look more closely at how they could increase the number of company-owned shops to boost their profitability.

\section{Support shop success}

Given the mixed success of initial franchisees, Farm Shop developed a system to evaluate the quality of its shop owners and rank them into "gold", "silver" and "bronze" categories according to their performance. "Gold" franchisees were rewarded with greater eligibility to access financing and participate in pilot projects testing new ideas. "Silver" and "bronze" franchisees were supported with targeted interventions wherever possible to address weaknesses and optimize business profitability.

\section{Margins}

Farm Shop discovered that selling agricultural inputs to smallholder farmers is a much lower margin business than anticipated, with average margins of $5 \%$ on sales over all products. Data showed that animal feed, which made up 75\% of Farm Shop's sales, had particularly low margins, at about $3.5 \%$. Suppliers were less willing than expected to give discounts even at the volume of demand generated by 74 shops. The existing network of relationships between suppliers, distributors, wholesalers and sub-distributors was more complex and difficult to disrupt than Farm Shop had anticipated.

\section{More margins from existing products}

Farm Shop needed to increase its margins. One strategy Farm Shop developed included selling more high-margin products, for example hay (25\% margin) and maize bran (10\% margin). They updated their information system to track and regularly report on sales margins for various product categories and assigned managers targets for increasing average margins on different types of products.

Overheads Looking at the numbers, Farm Shop found that overheads were higher than expected due to the startup nature of the organization and the commitment to many direct social impact activities, such as farmer training.

\section{New revenue streams}

Farm Shop began to explore new lines of business that would generate additional revenue streams. As an example of this, day-old chicks were added to Farm Shop's offerings.

\section{Separate for-profit and not-for-profit activities}

A main strategy to reduce Farm Shop's business operating costs was for Farm Shop to separate activities into those managed by Farm Shop retail (a for-profit organization) and those managed by Farm Shop NGO (a separate not-for-profit organization). By separating activities between the two organizational entities, Farm Shop aimed to reduce the costs to Farm Shop retail of farmer training, research and development and impact measurement, which would be funded through grants to Farm Shop NGO.

\section{Optimize supply chain efficiencies}

Farm Shop brought forward a number of strategies to reduce costs through achieving greater efficiencies in its supply chain from suppliers to franchisees. Importantly, Farm Shop hired an experienced new CEO with a background in distribution and supply chain and logistics management with a mandate to bring Farm Shop in line with best practices in retail franchise operations. Activities implemented included optimizing warehouse space and truck delivery routes, increasing direct purchasing from manufacturers (rather than wholesalers) and continually assessing market prices to ensure competitiveness while working toward reducing costs and increasing product margins. 


\section{Close unprofitable shops}

Although many Farm Shop franchisees were profitable, a number struggled, despite training and consistent handson support from Farm Shop staff. One of the most significant problems occurred when franchisees found themselves unable to reinvest profits into inventory, leading to a downward spiral in product availability, customer satisfaction and profitability. Closing the shops that are unprofitable, despite best efforts, reduced the drain on Farm Shop's resources and allowed staff to support the more successful shops, which created a virtuous cycle of income generation and serving smallholder farmers with the inputs and information needed.

\section{Lesson 5. Data is critical: to develop a scalable business} model, cost-effectively gathering the right data to validate key assumptions is essential

Data collection and management systems are essential to achieving scale, as they need to be used to gather the information that will test financial assumptions and validate elements of the business model. One of Farm Shop's lessons is that organizations in the early stage of development face challenging choices with respect to designing and investing in data systems. A first challenge is that developing these information systems are costly in terms of time and money. The second challenge is that in the early stages of business model development and iteration it is not always clear what the most important data points are to measure. As a board member explained, "We need the data systems and IT systems in place to source relatively accurate data. We were making a lot of assumptions based on imperfect data. To some degree that's fine-most start-ups and growing organizations have an issue with imperfect data because it costs an extraordinary amount to get perfect data. As you grow and evolve, the other problem is you're not even sure what data you need. With a lot of the underlying numbers, we didn't realize we needed these, or that these were critical numbers; we had to fundamentally change them over time as we analyzed which data points were really critical and which were not." Without accurate and timely data, the fundamentals of the business model cannot be tested and validated, which is an essential step on the path to scale.

\section{Conclusion}

Farm Shop is one of a cohort of pioneering social franchises that have applied the principles of franchising to address particular social needs. In this case, the needs were food security, livelihoods and prosperity for smallholder farmers. Like others experimenting with social franchising, Farm Shop has faced the work of developing a business model that could generate sufficient revenues to cover overhead costs and allow the network to cover its costs of capital and scale through market forces. On this journey, Farm Shop uncovered important lessons relevant for all social franchises at similar stages in the business model development process. Our experience shows that social franchising can create jobs and profitability for farmers and strengthens the rural entrepreneurial ecosystem. It also indicates that economies of scale are critical for the profitability and sustainability of the social franchise. Building trust with farmers is crucial for a successful social franchising model, and social franchisors should be aware of the variety of options for them to create sustainability. Finally, social franchisors must do everything possible to gather the business and financial data needed to test their model. With these lessons in mind, Farm Shop and other social franchises can be even better equipped to live up to social franchising's promise of achieving social objectives in a more resource-efficient, sustainable way and scalable way.

\section{Abbreviation \\ CIFSRF: Canadian international food security research fund.}

\section{Acknowledgements}

The authors would like to thank Heather Krause for her financial analysis and quantitative financial modeling, Jill McPherson for her research project management and assistance, Sarah Murray for her gender analysis and Garrick $\mathrm{Ng}$ for his work on documentation. Thanks also to the board and senior management team at Farm Shop for their collaboration including Madison Ayer, Christian Pennotti, Saida Karanja, Paul Gachie, Patricia Wandia, Faraya Ziswa, Kennedy Otingah, Francis Muli, Abigael Kutwa, Peter Nyambura, Paul Kiraguri, Edward Gatonye and Noah Kakai. Thank you to Bob Newbury at the University of Northumbria for ongoing research collaboration. We would also like to thank Marco Rondon, Jemimah Njuki, Simon Winter and Wendy Manchur at the International Development Research Centre for their support as part of the Canadian International Food Security Research Fund. Thank you also to University of Nairobi faculty colleagues Erasmus Kaijage and Duncan Elly and PhD students Moureen Agunga, Tabitha Njunguna, Margaret Kamakia and Paul Simidi for research on various aspects of Farm Shop.

\section{Authors' contributions}

FJ is a cofounder of Farm Shop and a senior leader in the organization's management. Research data were gathered by KM and KH. KM wrote the manuscript with input from $\mathrm{KH}, \mathrm{FJ}$ and $\mathrm{OE}$. All authors read and approved the final manuscript.

\section{Funding}

This research was funded by the Canadian International Food Security Research Fund, an initiative of the International Development Research Centre and Global Affairs Canada. The funders were not directly involved in the collection, analysis and interpretation of data or the development of the manuscript.

\section{Availability of data and materials}

The datasets used and/or analyzed during the current study are available from the corresponding author.

\section{Declarations}

Ethics approval and consent to participate

Ethics approval was obtained from Kenya's National Commission for Science, Technology and Innovation (NACOSTI/P/16/51513/8710) and Cape Breton University's Research Ethics Board (1718-066). 


\section{Consent for publication \\ Not applicable.}

\section{Competing interests}

$\mathrm{KM}, \mathrm{KH}$ and $\mathrm{OE}$ declare that they have no competing interests. FJ cofounded Farm Shop but sold his shares to local management and does not retain any financial interest in the organization.

\section{Author details}

${ }^{1}$ Shannon School of Business, Cape Breton University, Sydney, Canada. ${ }^{2}$ Coady International Institute, St. Francis Xavier University, Antigonish, Canada. ${ }^{3}$ Said Business School, University of Oxford, Oxford, England. ${ }^{4}$ University of Toronto, Toronto, Canada.

Received: 19 October 2020 Accepted: 8 June 2021

Published online: 01 November 2021

\section{References}

1. Acumen, bain and company. Growing prosperity: developing repeatable models to scale the adoption of agricultural innovations. 2014.

2. Agarwal M, and Satish D. Babban Gona's agri-franchising model; scaling up challenges. IBS center for management research. 2018.

3. Alon I, editor. Social franchising. Basingstoke: Palgrave Macmillan; 2014.

4. Anríquez G, Stamoulis K. Rural development and poverty reduction: Is agriculture still the key? Rome, Italy: Agricultural Development Economics Division, The Food and Agriculture Organization of the United Nations; 2007.

5. Barrett CB. Smallholder market participation: concepts and evidence from eastern and southern Africa. Food Policy. 2008;33(4):299-317.

6. Bill and melinda gates foundation. Agricultural development in Africa. Fact sheet. 2010

7. Christensen LJ, Parsons H, Fairbourne J. Building entrepreneurship in subsistence markets: microfranchising as an employment incubator. J Bus Res. 2010;63(6):595-601. https://doi.org/10.1016/j.jbusres.2009.03.020.

8. Christiaensen L, Demery L, Kuhl J. The (evolving) role of agriculture in poverty reduction - an empirical perspective. J Dev Econ. 2011;96(2):239-54. https://doi.org/10.1016/j.jdeveco.2010.10.006.

9. Diochon MC, Anderson AR, Ghore Y. Microfranchise emergence and its impact on entrepreneurship. Int Entrep Manag J. 2017;13(2):553-74. https://doi.org/10.1007/s11365-016-0414-7.

10. Fairbourne JS, Gibson SW, Dyer WG. Microfranchising: Creating wealth at the bottom of the pyramid. Edward Elgar Publishing; 2007.

11. Fan $S$, Rue C. The role of smallholder farms in a changing world. In the role of smallholder farms in food and nutrition security. Springer. 2020.

12. FAO. Ending poverty and hunger by investing in agriculture and rural areas. Food and agriculture organization of the united nations, 20. 2017.

13. FAO. The role of agriculture and rural development in achieving SDG 1.1. Ending extreme rural poverty. Paper for presentation at the United Nations expert group meeting on eradicating rural poverty to implement the 2030 agenda for sustainable development, UNECACC-AA. 2019. https://www.un.org/development/desa/dspd/wp-content/uploads/ sites/22/2019/03/FAO-ending-extreme-rural-poverty-1.pdf. Accessed 1 May 2021.

14. Farm Africa. Farm Africa launches groundbreaking business model. 2011. https://www.farmafrica.org/latest/news/post/146-farm-africa-launchesground-breaking-business-model. Accessed 1 May 2021.

15. Godfray C, Beddington J, Crute I, Haddad L, Lawrence D, Muir J, Pretty J, Robinson S, Thomas S, Toulmin C. Food Security: the challenge of feeding 9 billion people. Science. 2010;327(5967):8128. https://doi.org/10.1126/ science 1185383.
16. Hystra. Smallholder farmers and business: 15 pioneering collaborations for improved productivity and sustainability. Hystra. 2015.

17. Jensen RJ, Sutter C. A model to explain microfranchising in bottom of the pyramid markets. Brigh Young Univ Int law Manag Rev. 2009;5(2):189-206.

18. Jiwa F. Honey care Africa. In: Microfranchising: Creating wealth at the bottom of the pyramid. Cheltenham: Edward Elgar; 2007. p. 149-63.

19. Kenya markets. Boosting Agricultural productivity through franchising: The Case of Farmers Pride. 2017. https://www.kenyamarkets.org/boost ing-agricultural-productivity-franchising-case-farmers-pride/. Accessed 1 May 2021.

20. Kistruck G, Webb J, Sutter C, Ireland D. Microfranchising in base-ofthe-pyramid markets: institutional challenges and adaptations to the franchise model. Entrep Theor Pract. 2011. https://doi.org/10.1111/j.15406520.2011.00446.x.

21. Langyintuo A. Smallholder farmers' access to inputs and finance in Africa. The role of smallholder farms in food and nutrition security. Springer, Cham. 2020 p; 133-152.

22. McKague, K., Harji, K., Jiwa, F. Farm shop: lessons learned from scaling a social franchise. Ottawa: international development research centre. 2018.

23. McKague K, Menke M, Arasaratnam A. Access afya: micro-clinic health franchise designed for scale. Social franchising. Basingstoke, UK: Palgrave Macmillan; 2014. p. 61-79.

24. McKague K, Siddiquee M. Making markets more inclusive. New York: Palgrave Macmillan; 2014.

25. McKague K, Wong J, Siddiquee N. Social franchising as rural entrepreneurial ecosystem development: the case of Krishi Utsho in Bangladesh. Int J Entrep Innov. 2017;18(1):47-56. https://doi.org/10.1177/1465750316 686240.

26. Mitchell K. Micro-opportunity alternative: microfranchising. Washington, DC: Center for Financial Inclusion; 2013. https://www.centerforfinancialin clusion.org/micro-opportunity-alternative-microfranchising. Accessed 1 May 2021.

27. Mondiale B. World development report: agriculture for development. Washington, DC: The World Bank; 2008.

28. Mutero J, Munapo E, Seaketso P. Operational challenges faced by smallholder farmers: a case of Ethekwini Metropolitan in South Africa. Environ Econ. 2016;7(2):40-52. https://doi.org/10.2151/ee.07(2).2016.4.

29. Pennotti C, Fawley-King T. The ADAPT project in Zambia: Successes and lessons in building a scalable network of rural agro-dealers to serve smallholders. Care USA. 2010

30. Rigter H, Fischer M, Friscic L, Kipker S. An assessment report: micro-franchising: a viable and sustainable business model for the Swiss development cooperation agency? 2014.

31. Santeramo FG. On the composite indicators for food security: decisions matter! Food Rev Intl. 2015;31(1):63-73.

32. Sukhpal, S. Innovative agricultural inputs marketing models in India: performance and potential. Centre for management in agriculture. Indian institute of management Ahmedabad. 2016.

33. World Food Programme. Changing lives for smallholder farmers. Beyond the annual performance report. Washington, DC: World Food Programme; 2019. https://docs.wfp.org/api/documents/WFP-0000110345/ download/. Accessed 1 May 2021.

\section{Publisher's Note}

Springer Nature remains neutral with regard to jurisdictional claims in published maps and institutional affiliations. 